\title{
Profile and Lifestyle of Hypertensive Patients, Cardiovascular Comorbidity, and Complications in a Primary Health Center in Surabaya, Indonesia
}

Sulistiawati Sulistiawati ${ }^{1 *}$, Linda Dewanti ${ }^{1}$, Adikara Pagan Pratama ${ }^{1}$, Atika Atika $^{1}$, Widati Fatmaningrum ${ }^{1}$, Djohar Nuswantoro ${ }^{1}$, Tan Nicko Octora ${ }^{2}$, Dyah Ayu Pradnyaparamitha², Fahmi Aulia Rizqi ${ }^{2}$

${ }^{1}$ Department of Public Health and Preventive Medicine, Faculty of Medicine, Universitas Airlangga, Surabaya, Indonesia; ${ }^{2}$ Faculty of Medicine, Universitas Airlangga, Surabaya, Indonesia

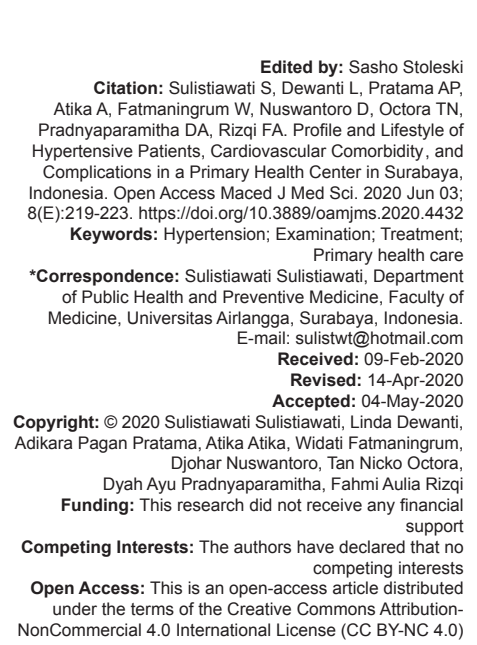

Introduction

The WHO reported that in 2002, the prevalence of hypertension was $15-37 \%$ of the adult population worldwide. Half of the world's population above 60 years old was suffered from hypertension. The WHO data in September 2011 showed that hypertension was responsible for 8 million deaths per year worldwide and 1.5 million deaths per year in the Southeast Asia region [1]. Hypertension ranked the third most common disease at the outpatient clinics in Indonesia in 2004 and escalated to the second rank (4.67\%) in 2006. Survey of the risk factors for cardiovascular disease showed that the prevalence of hypertension in Indonesia increased to $13.6 \%$ in men and $16 \%$ in women [2].

This study conducted at Primary Health Center (PHC) in Banyu Urip district, Surabaya, which represents the urban district in Indonesia. Availability of medical tools, medication, and human resource might be better than PHC in rural or in isolated areas of Indonesia. This study describes the result of hypertension management in PHC level in Indonesia.

Hypertensive patients experience a disruption in productivity, such as inability to work (4\%) and $28.2 \%$ sick leave over the past year [3]. The productivity level of hypertensive patients was strongly determined by doctor's performances in $\mathrm{PHC}$ and patients' compliance in managing the disease. Those two features together have an important role in preventing complications. This study aimed to analyze the profile and lifestyle of hypertensive patients and health services in primary health facilities as one of the catastrophic diseases in Indonesia.

\section{Methods}

This study was conducted by observing hypertensive patients. The sample size was all 
hypertensive patients who came for health examinations in the past 3 months at one of the PHC on Surabaya in 2018, comprising 104 patients. Variables measured in this study were respondent characteristics, diet pattern, physical activity, patient's socioeconomic conditions, genetic factors, pharmaceutical and non-pharmaceutical therapy from primary health services, controlled blood pressure status, hypertensive comorbidities, and hypertensive complications. Data were collected using primary (questionnaires as well as physical and laboratory examinations) and secondary data (medical records). This study received approval from the Ethics Committee, Faculty of Medicine, Universitas Airlangga, no. 167/EC/KEPK/FKUA/2018.

\section{Results}

Table 1 showed that more than half of patients aged above 60 (57.7\%). The majority of patients had a low educational background $(66.3 \%)$. Most of the patients did not actively work due to retirement $(8.6 \%)$ and be housewives (51\%). The total family income per month was dominantly under USD 200 (73.1\%).

Table 1: Characteristics and profile of hypertensive patients

\begin{tabular}{|c|c|c|}
\hline Variables & Frequency $(\mathrm{n})$ & Percentage \\
\hline \multicolumn{3}{|l|}{ Sex } \\
\hline Male & 24 & 23.1 \\
\hline Female & 80 & 76.9 \\
\hline \multicolumn{3}{|l|}{ Age } \\
\hline $18-39$ & 3 & 2.9 \\
\hline $40-59$ & 41 & 39.4 \\
\hline$\geq 60$ & 60 & 57.7 \\
\hline \multicolumn{3}{|l|}{ Education } \\
\hline No formal education & 6 & 5.8 \\
\hline Elementary school & 33 & 31.7 \\
\hline Junior high school & 30 & 28.8 \\
\hline Senior high school & 28 & 26.9 \\
\hline High education & 7 & 6.7 \\
\hline \multicolumn{3}{|l|}{ Occupation } \\
\hline Merchant & 16 & 15.4 \\
\hline Housewives & 53 & 51 \\
\hline Retired & 9 & 8.6 \\
\hline Others & 26 & 25 \\
\hline \multicolumn{3}{|l|}{ Income (USD/months) } \\
\hline$<200$ & 76 & 73.1 \\
\hline $200-400$ & 21 & 20.2 \\
\hline$>400$ & 7 & 6.7 \\
\hline \multicolumn{3}{|l|}{ Degree of hypertension (early treatment) } \\
\hline Hypertension degree 1 & 41 & 39.4 \\
\hline Hypertension degree 2 & 63 & 60.6 \\
\hline \multicolumn{3}{|l|}{ Degree of hypertension (during research) } \\
\hline Controlled (normal and pre-hypertension) & 32 & 30.7 \\
\hline Hypertension degree 1 & 54 & 51.9 \\
\hline Hypertension degree 2 & 16 & 15.4 \\
\hline Hypertension degree 3 & 2 & 1.9 \\
\hline \multicolumn{3}{|l|}{ Duration of hypertension (years) } \\
\hline$\leq 10$ & 81 & 77.9 \\
\hline $11-20$ & 18 & 17.3 \\
\hline$>20$ & 5 & 4.8 \\
\hline \multicolumn{3}{|c|}{ Duration of hypertension treatment at the health center (years) } \\
\hline$\leq 5$ & 86 & 82.7 \\
\hline $6-10$ & 11 & 10.6 \\
\hline$>10$ & 7 & 6.7 \\
\hline \multicolumn{3}{|l|}{ Medication regularity } \\
\hline Highly regular & 64 & 61.5 \\
\hline Less regular & 27 & 26.0 \\
\hline Not regular & 13 & 12.5 \\
\hline
\end{tabular}

This study also showed that $69.2 \%$ of the patients did not achieve the target blood pressure. Most of them were in Stage 1 hypertension (51.9\%). The majority were suffered from the disease for $<10$ years
(77.9\%), but mostly they came to $\mathrm{PHC}$ in the past 5 years $(82.7 \%)$. Most of the patients committed taking the medication regularly $(61.5 \%)$.

Table 2 showed that the symptom that patient complained the most was tension-type headache $(45.2 \%)$, while the less was vertigo $(9.6 \%)$. Electrocardiogram in $27.9 \%$ was abnormal. Ischemia and infarction were found in 18 cases (17.3\%). The abnormal condition that was an indication of hypertensive complications was dominated by ischemic and old myocardial infarction, which was found in $62.1 \%$ of patients with an abnormal ECG.

Table 2: Profile of clinical symptoms of hypertension and ECG profile

\begin{tabular}{lll}
\hline Symptoms & Frequency $(\mathrm{n})$ & Percentage \\
\hline Headache & 32 & \\
Often & 44 & 30.8 \\
Seldom & 28 & 42.3 \\
Never & & 26.9 \\
Vertigo & 10 & \\
Often & 32 & 9.6 \\
Seldom & 62 & 30.8 \\
Never & & 59.6 \\
Back neck pain & 47 & \\
Often & 30 & 45.2 \\
Seldom & 27 & 28.8 \\
Never & 75 & 26.0 \\
Normal ECG & - & 72.1 \\
Abnormal ECG & 1 & - \\
AF with rapid ventricular response & 3 & 1.0 \\
Complete RBBB & 2 & 2.9 \\
Incomplete RBBB & 2 & 1.9 \\
Anterior ischemia & 4 & 1.9 \\
Anterolateral ischemia & 3 & 3.8 \\
Anteroseptal ischemia & 2 & 2.9 \\
Left atrial abnormality & 1 & 1.9 \\
Occasional PVC, ischemia anterior & 1 & 1.0 \\
Anterior OMI & 2 & 1.0 \\
Anteroseptal OMI & 2 & 1.9 \\
Anterosptal OMI & 1 & 1.9 \\
Inferior OMI & 1 & 1.0 \\
Inferior OMI & 1 & 1.0 \\
PAC & 1 & 1.0 \\
PVC, OMl anteroseptal & 2 & 1.0 \\
S persistent V1-V6 & & 1.9 \\
\hline OMl: Old myocardial infarction, PVC: Premature ventricular complex, PAC: Premature atrial contraction, \\
ECG: Electrocardiography. & & \\
& &
\end{tabular}

Table 3 showed that most of the patients ate healthy food and never drank coffee or alcohol. The majority of them rarely eat vegetables/fruit and fatty foods. The majority of the hypertensive patients never exercised, but most claimed not to smoke. Most of the patients received education about a healthy diet, taking medication, and visiting $\mathrm{PHC}$ regularly from a doctor in $\mathrm{PHC}$.

Table 4 showed that patients had a high level of total cholesterol and blood sugar, while their uric acid levels were normal, despite one patient with $9.00 \mathrm{mg} / \mathrm{dL}$ uric acid level. Normal total cholesterol levels were found in 49 patients $(49.5 \%)$, while hypercholesterolemia was found in 50 patients $(50.5 \%)$. Normal fasting blood sugar levels were found in 62 patients $(61.4 \%)$, while 39 patients $(38.6 \%)$ were suffered from diabetes. Normal uric acid levels were found in 89 patients (89.9\%), while 10 patients were at high levels (10.1\%).

Table 5 showed the effectiveness in therapy was dominated by combination therapy. The types of antihypertensive drugs taken were captopril, amlodipine, and others, given both in monotherapy and in combination, depending on the stage of hypertension. 
Table 3: History of consumed food, alcohol, smoking, habit, diet education, and exercise

\begin{tabular}{|c|c|c|}
\hline Consumption & Frequency (n) & Percentage \\
\hline \multicolumn{3}{|l|}{ Salty foods } \\
\hline Often & 38 & 36.5 \\
\hline Seldom & 48 & 46.2 \\
\hline Never & 18 & 17.3 \\
\hline \multicolumn{3}{|l|}{ Cow meat } \\
\hline Often & 28 & 26.9 \\
\hline Seldom & 21 & 20.2 \\
\hline Rarely & 47 & 45.2 \\
\hline Never & 8 & 7.7 \\
\hline \multicolumn{3}{|l|}{ Goat meat } \\
\hline Often & 3 & 2.9 \\
\hline Seldom & 12 & 11.5 \\
\hline Rarely & 35 & 33.7 \\
\hline Never & 54 & 51.9 \\
\hline \multicolumn{3}{|l|}{ Salted fish } \\
\hline Often & 9 & 8.7 \\
\hline Seldom & 19 & 18.3 \\
\hline Rarely & 37 & 35.6 \\
\hline Never & 39 & 37.5 \\
\hline \multicolumn{3}{|c|}{ Canned meat/fish } \\
\hline Often & 0 & 0 \\
\hline Seldom & 14 & 13.5 \\
\hline Rarely & 27 & 26.0 \\
\hline Never & 63 & 60.5 \\
\hline \multicolumn{3}{|l|}{ Vegetables } \\
\hline Often & 75 & 72.1 \\
\hline Seldom & 14 & 13.5 \\
\hline Rarely & 11 & 10.6 \\
\hline Never & 4 & 3.8 \\
\hline \multicolumn{3}{|l|}{ Fresh fruit } \\
\hline Often & 62 & 59.6 \\
\hline Seldom & 17 & 16.3 \\
\hline Rarely & 22 & 21.2 \\
\hline Never & 3 & 2.9 \\
\hline \multicolumn{3}{|l|}{ Fatty food } \\
\hline Often & 46 & 44.2 \\
\hline Seldom & 22 & 21.2 \\
\hline Rarely & 33 & 31.7 \\
\hline \multirow{2}{*}{\multicolumn{3}{|c|}{ Coffee }} \\
\hline & & \\
\hline Often & 21 & 20.2 \\
\hline Seldom & 16 & 15.4 \\
\hline Rarely & 25 & 24.0 \\
\hline Never & 42 & 40.4 \\
\hline \multicolumn{3}{|l|}{ Alcohol } \\
\hline Rarely & 1 & 1.0 \\
\hline Never & 103 & 99.0 \\
\hline \multicolumn{3}{|l|}{ Smoking habit } \\
\hline Often & 6 & 5.8 \\
\hline Seldom & 2 & 1.9 \\
\hline Rarely & 2 & 1.9 \\
\hline Never & 94 & 90.4 \\
\hline \multicolumn{3}{|l|}{ Exercise habit } \\
\hline Often & 37 & 35.6 \\
\hline Seldom & 10 & 9.6 \\
\hline Rarely & 15 & 14.4 \\
\hline Never & 42 & 40.4 \\
\hline Obtaining edu & & \\
\hline Yes & 79 & 76.6 \\
\hline No & 24 & 23.3 \\
\hline Education on & & \\
\hline Often & 85 & 81.7 \\
\hline Seldom & 10 & 9.6 \\
\hline Rarely & 3 & 2.9 \\
\hline Never & 6 & 5.8 \\
\hline Education on & & \\
\hline Often & 85 & 81.7 \\
\hline Seldom & 11 & 10.6 \\
\hline Rarely & 2 & 1.9 \\
\hline Never & 6 & 5.8 \\
\hline
\end{tabular}

\section{Discussion}

\section{Characteristics of the patients}

Hypertensive patients were dominated by the age of over 60 years. Age distribution in this research was similar to other research because of the pathophysiology of the disease, namely arterial stiffness has occurred in older age. Based on gender, the patients were dominated by women. Research conducted by August $P$. in 2013 showed that the prevalence of hypertension was
Table 4: Laboratory results

\begin{tabular}{llllll}
\hline Laboratory & Sample size & Minimum & Maximum & Mean & Standard deviation \\
\hline Fasting blood glucose & 101 & 68 & 439 & 139.71 & 68.764 \\
Cholesterol & 99 & 119 & 351 & 207.01 & 47.344 \\
Uric acid & 99 & 2.0 & 9.0 & 4.433 & 1.3748 \\
\hline
\end{tabular}

higher among men up to middle-age in all ethnicity. After middle age, the prevalence of hypertension was higher in women [4]. A particular case in women often found white coat hypertension and very varied systolic blood pressure [5]. The fact that hypertension prevalence in this research was higher in women aged over 65 years old due to the longer life expectancy of women. Nearly $75 \%$ of post-menopausal women in America suffer from hypertension [6]. In this study, since there were more hypertensive patients in the age group of 60 years or more, the proportion of women was also higher. The educational background was dominated by junior high school or less. The majority of patients were housewives with monthly family income which was under USD 200.

Table 5: Comparison between monotherapy and combination therapy in controlling hypertension

\begin{tabular}{llll}
\hline Blood pressure & Therapy & $\begin{array}{l}\text { Frequency } \\
(\mathrm{n})\end{array}$ & $\begin{array}{l}\text { Mean }(\mathrm{mmHg}) \text { of the } \\
\text { decrease on blood pressure }\end{array}$ \\
\hline Systolic blood pressure $^{*}$ & Monotherapy & 64 & -17.80 \\
& Combination & 38 & -26.32 \\
Diastolic blood pressure $^{* *}$ & Monotherapy & 62 & -5.95 \\
& Combination & 37 & -10.41 \\
\hline${ }^{*}$ Comparative study independent t-test, $\mathrm{p}=0.049 .{ }^{* *}$ Comparative study & Mann-Whitney test, $\mathrm{p}=0.066$.
\end{tabular}

There were hypertension stage 1 and 2 at the beginning of diagnosed (obtained from the medical record), but a change happened during the study. Some of them increased to stage 3 , but some became normal and decreased to pre-hypertensive (categorized as controlled conditions). That fact showed that not all of patients' blood pressure was regulated due to pathophysiological basis on age theory (the higher the age and the higher the risk of increasing blood pressure) even though the patient obtained sufficient therapy. Regulated blood pressure is determined by various factors, including the regularity of taking medication, diet patterns, exercise, stress levels, and others.

Early detection of hypertension in patients was found in several health examination centers, such as primary health centers, hospitals, and private clinics or during social services. Symptoms complained were not specific because the patients rarely complained headaches but, more often, only pain behind the neck so that because the complaint was not specific, the patient was less able to detect an increase in blood pressure.

\section{Overview of diet, exercise habits, and drinking coffee in hypertensive patients}

This study showed that hypertensive patients have a proper diet, for example, they rarely consumed salty food or salted fish and beef. Most of them informed us that they never ate goat meats, never drank coffee, alcohol, and often ate fresh vegetables and fruit. Even so, most patients still admitted consuming fatty 
foods; thus, most of them claimed to be suffered from dyslipidemia. In addition to hypertension, abdominal adipose deposits also play a role in the pathogenesis of coronary heart disease, sleep apnoea, and cerebrovascular accidents [7], [8].

Results of laboratory tests showed that the average of total cholesterol and random blood sugar was high. Diabetes mellitus and dyslipidemia were diseases that commonly found in conjunction with hypertension. The National Health and Nutrition Examination Survey (NHANES III) showed that $64 \%$ of hypertensive patients being suffered from dyslipidemia, and conversely, $47 \%$ of patients with dyslipidemia also suffering from hypertension [9]. In addition to dyslipidemia, diabetes mellitus was a disease that coincides with hypertension. According to Ferrannini and Cushman (2012), the proportion of hypertension in the type 2 diabetes mellitus population was quite high [10].

Most hypertensive patients never exercised, but most claimed not to drink coffee. Unfortunately, both variables were not significant in affecting hypertension statistically in this study $(p=0.640$ and $p=0.730$, respectively). The exercise was one of the factors that can affect hypertension because it increases physical activity (adequate physical activity), which in line with the guidelines to prevent hypertension [11]. Kim et al. (2010) showed that adults from Korea who exercise regularly have a slower progression from pre-hypertension to hypertension compared to people who do not do routinely exercise [12]. In this study, the diet pattern of hypertensive patients was good. The patients often ate fresh vegetables and fruits. Vegetables and fresh fruit are sources of polyphenols which are antioxidants and are needed to reduce the risk of cardiovascular disease and degenerative diseases [13]. Another good behavior we found was that hypertensive patients rarely ate meat and salty foods. A diet pattern that was still not obeyed by the patient was consuming fatty foods, even the health-care provider had told them to avoid.

Lifestyles need to be improved: Losing weight in obesity, reducing drinking alcohol, increasing aerobic physical activity, reducing salt intake, maintaining adequate potassium intake, maintaining adequate calcium and magnesium intake, stopping in smoking, and reducing intake of saturated fat and cholesterol [14]. Research held in Pekanbaru, Indonesia, showed that smoking behavior dominantly affects uncontrolled blood pressure in older adult hypertensive patients $(p=0.004$, odds ratio: 5.2 95\% confidence interval: 1.71-15.8) due to increase of blood pressure and heart rate during smoking [15].

\section{Management of hypertensive patients (treatment, education, and support for hypertensive patients) in PHC}

Pharmacologic treatment of hypertension in $\mathrm{PHC}$ was done with limited types of anti-hypertensive drugs, such as captopril, amlodipine, and others, either by monotherapy or combination, generally depending on the stage of hypertension and the availability of drugs. For patients with hypertension plus impaired heart function and congestive heart failure, usage of diuretics, angiotensin-converting-enzyme inhibitors, or a combination of both was the best choice [16] If blood pressure was controlled in the early stage of the disease, it will resulted on the better prevention of cardiovascular complications. Thus, two-drug combination is recommended to be given at the first use of therapy, in addition, that the possible side effect of the maximum dose of monotherapy can be reduced [17]. Nevertheless, it is depended on the doctors who prescribe, but they were standardized by the Indonesian Ministry of Health using guidelines by JNC VIII.

Non-pharmacological treatment, such as education to prevent the complication must be done by any health-care provider in PHC. For example, the doctors or nurses reminded the patients to take medication regularly, to visit for examination, and to avoid foods that have a role as the risk of increasing high blood pressure. As with younger people, this non-pharmacological intervention must be started before using drugs [18]. Hence, the majority of hypertensive patients filled the questionnaires that they received education from the health-care provider in PHC in Surabaya, especially by the doctors. This means that one program for disease prevention with education has been well-provided.

\section{Conclusion}

Regarding supportive examination for screening and the detection of risk factors and complications, most of the patients suggested the check for diabetes mellitus as well as dyslipidemia as a regular examination. However, the ECG examination rarely been done. This study showed that nearly onethird of the patients (27.9\%) had ECG abnormalities, so it would come to be a suggestion to PHC to do ECG examination routinely in hypertensive patients.

\section{References}

1. Ministry of Health. Riset Kesehatan Dasar/Basic Health Research. Jakarta: Ministry of Health; 2013. Available from: http://labdata.litbang.kemkes.go.id/images/download/laporan/ RKD/2013/Laporan_riskesdas_2013_final.pdf. [Last accessed on 2020 May 04].

2. Widyasari N. Relationship of respondent's characteristic with the risk of diabetes mellitus and dyslipidemia at tanah kalikedinding. J Berk Epidemol. 2017;5:130-41. https://doi.org/10.20473/jbe. v5i12017.130-141 
3. Krstović-Spremo V, Račić M, Joksimović BN, Joksimović VR. The effects of diabetes mellitus and hypertension on work productivity. Acta Med Acad. 2014;43(2):122-33. https://doi. org/10.5644/ama2006-124.111

PMid:25529517

4. August P. Hypertension in women. Adv Chronic Kidney Dis. 2013;20(5):396-401.

\section{PMid:23978544}

5. Kaplan NM. Review of hypertension in practice, Third Edition. J Hum Hypertens. 1999;13(9):647.

PMid:10482977

6. Ong KL, Tso AW, Lam KS, Cheung BM. Gender difference in blood pressure control and cardiovascular risk factors in Americans with diagnosed hypertension. Hypertension. 2008;51(4):1142-8. https://doi.org/10.1161/hypertensionaha.107.105205

PMid:18259031

7. Stritzke J, Markus MR, Duderstadt S, Lieb W, Luchner A, Döring $A$, et al. The aging process of the heart: Obesity is the main risk factor for left atrial enlargement during aging. The MONICA/KORA (monitoring of trends and determinations in cardiovascular disease/cooperative research in the region of Augsburg) Study. J Am Coll Cardiol. 2009;54(21):1982-9. https://doi.org/10.1016/j.jacc.2009.07.034

PMid: 19909880

8. Narkiewicz K. Obesity and hypertension-the issue is more complex than we thought. Nephrol Dial Transplant. 2006;21(2):264-7. https://doi.org/10.1093/ndt/gfi290

PMid:16311261

9. Egan B, Li J, Qanungo S, Wolfman TE. Blood pressure and cholesterol control in hypertensive hypercholesterolemic patients: National health and nutrition examination surveys 1988-2010. Circulation. 2013;128(1):29-41. https://doi. org/10.1161/circulationaha.112.000500 PMid:23817481

10. Ferrannini E, Cushman WC. Diabetes and hypertension: The bad companions. Lancet. 2012;380(9841):601-10. https://doi. org/10.1016/s0140-6736(12)60987-8

PMid:22883509
11. Diaz KM, Shimbo D. Physical activity and the prevention of hypertension. Curr Hypertens Rep. 2013;15(6):659-68. https:// doi.org/10.1007/s11906-013-0386-8

PMid:24052212

12. Kim SJ, Lee J, Jee SH, Nam CM, Chun K, Park IS, et al. Cardiovascular risk factors for incident hypertension in the prehypertensive population. Epidemiol Health. 2010;32:e2010003. https://doi.org/10.4178/epih/e2010003 PMid:21191456

13. Mohamed S. Functional foods against metabolic syndrome (obesity, diabetes, hypertension and dyslipidemia) and cardiovasular disease. Trends Food Sci Technol. 2014;35(2):114128. https://doi.org/10.1016/j.tifs.2013.11.001

14. Kotchen TA, McCarron DA. Dietary electrolytes and blood pressure. Circulation. 1998;98(6):613-7.

15. Mitra M, Wulandari W. Factors affecting uncontrolled blood pressure among elderly hypertensive patients in Pekanbaru city, Indonesia. Open Access Maced J Med Sci. 2019;7(7):1209-13. https://doi.org/10.3889/oamjms.2019.255

PMid:31049109

16. Bulpitt CJ, Fletcher AE, Thijs L, Staessen JA, Antikainen R, Davidson $\mathrm{C}$, et al. Symptoms reported by elderly patients with isolated systolic hypertension: Baseline data from the SYST-EUR trial. Systolic hypertension in Europe. Age Ageing. 1999;28(1):15-22. https://doi.org/10.1093/ageing/28.1.15 PMid:10203199

17. Mancia G, Rea F, Corrao G, Grassi G. Two-drug combinations as first-step antihypertensive treatment. CircRes. 2019;124(7):111323. https://doi.org/10.1161/circresaha.118.313294 PMid:30920930

18. Bulpitt CJ, Rajkumar C, Cameron JD. Vascular compliance as a measure of biological age. J Am Geriatr Soc. 1999;47(6):657-63. PMid:10366163 